\title{
REVIEW ON OPPORTUNITIES, CONSTRAINTS AND CONTRIBUTIONS OF INDUSTRIAL DEVELOPMENT ON ECONOMIC GROWTH IN ETHIOPIA
}

\author{
Alemayehu Oljira and Fenet Belay \\ ${ }^{1}$ Department of Agricultural Economics and Agribusiness Management Jimma University College of \\ Agriculture and Veterinary Medicine \\ ${ }^{2}$ Department of Rural Development and Agricultural Extension Jimma University College of Agriculture and \\ Veterinary Medicine \\ *corresponding author: alemayehu2016@gmail.com
}

\begin{abstract}
This paper is designed to review opportunities, constraints and contributions of industrial development on economic growth in Ethiopia. Sources such as scholarly publication, News and magazines, Books and chapters, Conference proceedings, government documents, theses and Dissertations have been reviewed. The review result indicates that industrial sector have substantial contribution to economic growth that helps to create a large portion of the resources needed to fund social development programs in the country. In addition, creation of employment and hence generation of income take place in the sector directly and are indirectly fostered in other sectors like agriculture or services through their linkages to industry. However, financial constraints, shortage of raw materials supply and lack of skilled manpower were identified as the main obstacles to the development of the sector. Finally the review argues that high rate of capital accumulation is a necessary condition for bringing about structural transformation and increased level of production and productivity to give rise for industrialization and the use of appropriate combination of skilled manpower, modern and suitable technologies and investment on both public infrastructures and manufacturing activities should be made.
\end{abstract}

Keywords: industrial sector, contribution of industry, constraints, opportunities, Ethiopia

http://dx.doi.org/10.21776/ub.agrise.2019.019.2.3

Received 03 January 2019

Accepted 23 April 2019

Available online 25 May 2019

\section{INTRODUCTION}

Industrialization is seen as a motor behind many of the processes usually termed as "social transformation" and "modernization " in terms of at least three ways in which industry helps to achieve the goals of social development. First, manufacturing industry's substantial contribution to economic growth that helps to create a large portion of the resources needed to fund social development programs. In addition, creation of employment and hence generation of income take place in the sector directly and are indirectly fostered in other sectors like agriculture or services through their linkages to industry. Finally, it promotes various aspects of social integration through its general thrust towards modernization (MoFED 2006).

In Ethiopia while the awareness about the need for industrialization is traced back to the early 1960 s, the design of comprehensive strategy with structural transformation in mind has come very late, with the 2004 declaration of the Ethiopian Industrial Development Strategy Document. "Though a favorable policy package to introduce 
and develop a modern economy was in place, there was not any deliberately drawn and explicitly specified industrial policy to accelerate industrialization in the country". The 2004 document put in place an articulated industrial development strategy for the first time (Admit Zerihun, 2008).

GTP period has seen increased investment and new capacities created in the industrial sectors. The investment is notable in textile and garment, leather, food and beverages, sugar, metals and engineering, pharmaceuticals, chemicals and construction materials industries. Coupled with existing capacities these developments are positive signs for Ethiopia's industrialization and structural transformation. To address one of the critical constraints of the private sector, the government has invested significantly in developing industrial zones. Accordingly, it has issued new laws and established support institution for industrial zone development. So far industrial zone development in Addis Ababa, Awasa, Dire Dawa and Kombolcha are in different stages of development.

Privatization of public enterprises is another strategy pursued to promote the development of the private sector. Accordingly, in the past three years of GTP, a total of 37 public enterprises (14 enterprises in 2010/11, fiscal year 13 enterprises in 2011/12 and 5 enterprises 2012/13) were privatized through selling (32 enterprises) and joint development (5 enterprises). Although the share of the overall industry sector in GDP showed a modest increase from about $13 \%$ in $2009 / 10$ to over $14 \%$ this was largely driven by the construction sector whose contribution in GDP nearly doubled during the period. The Ethiopian economy is one of the least industrialized and its manufacturing sector is least developed in many respects; in terms of volume and quality products, technology status, labor skills and export capabilities. For any economy, sustained industrial manufacturing growth rate has a great role in international competing. Without growth, industrial expansion in general and competitiveness in international markets in particular will not be possible. Thus, reviewing the opportunities, constraints and contributions of industrial development economic growth in Ethiopia is indispensable.

\section{REVIEW METHOD}

A systematic review method was used to review literature related to industrial development and its contribution on economic development in Ethiopia. A realist review approach was used. The realist approach builds up on the principles of the Cochran systematic review, however seeks explanation, rather than empirical truth (Pawson et al., 2005).

The realist review often includes tighter inclusion criteria and a small number of documents than other review approaches, with a focus on depth rather than breadth and the use of predominantly qualitative critical analyses. This method provides an appropriate tool to understand the constraints, opportunities and contributions of industrial development on economic growth in Ethiopia. To include only up to date information, a maximum time frame of 10 years is usually placed on the age of the works to be included in the review. Manual searching and Google scholar search strategies were performed in this literature review from different data bases. Finally, the full text documents were assessed to evaluate the relevance of the paper particularly for this review. Papers both published and unpublished in English language were reviewed.

\section{DISCUSSION}

\section{The Evolution of Industrial Sector in Ethiopia}

In Ethiopia, modern manufacturing factories emerged in 1920s (As of 1927 about 25 were set up mostly by foreigners) the sector started to get momentum in the 1950s (after brief disruption in the WWII period). The 1950s also marked by start of a comprehensive plan to promote the country's industrial \& economic development. Ethiopia has seen three regimes over the last eight decades Imperial regime (up to 1974) - Dergu regime (1974-91) - EPRDF-led regime (since 1991). The imperial regime (up to 1974) between 1958-73 three successive development plans was implemented.

The implementation of the initiatives attracted foreign investors and boost the manufacturing sector (World Bank, 1985). But by the end of the Imperial regime the overall industrial base was weak. The manufacturing sector characterized by dual structure - The modern sector constituted few hundreds of factories employing no more than 
60,000 people and dominated by import substituting light industries and foreign ownership (Shiferaw, J. 1995).

The Derge regime (1974 to 1991) No specific industrial policy per se until mid-1980s, but nationalized most of the MLSM enterprises declared "a socialist economic policy' - put various restrictions on the private sector \& market - Nationalized enterprises SOEs reorganized under state corporations. The manufacturing sector shrunk and the private sector virtually reduced into micro \& small manufacturing activity. The EPRDF-led government (since 1991) the first decade (1991-99) marked by various reforms reversing the command economy Implemented three phases of IMF/WB sponsored reform programs. In 1998 government adopted Export Promotion Strategy A full-fledged Industrial Development Strategy (IDS) was formulated in 2002/03 - Concretized into action by various subsector strategies and by the successive development plans such as; Sustainable Development and Poverty Reduction Program (SDPRP) 2002/032004/05 and the Plan of Action for Sustainable Development and Eradication of Poverty (PASDEP) 2005/06-2009/10 (Szirmai, A. 2009).

Table 1: The Ethiopian industrial policy and development phases

\begin{tabular}{|c|c|c|c|}
\hline & $\begin{array}{l}\text { Imperial period } \\
\quad \text { (Pre 1974) }\end{array}$ & $\begin{array}{l}\text { The Dergue regime } \\
(1975-91)\end{array}$ & $\begin{array}{l}\text { The EPRDF regime } \\
\text { (Post 1992) }\end{array}$ \\
\hline Guiding Policy/Vision & Market oriented & Command Economy & Market Oriented \\
\hline Public /Private role & Private led & State led & $\begin{array}{l}\text { Private led but also strong } \\
\text { state }\end{array}$ \\
\hline Ownership structure & $\begin{array}{l}\text { Dominance of foreign } \\
\text { owned enterprises }\end{array}$ & $\begin{array}{l}\text { Dominance of public owned } \\
\text { enterprises }\end{array}$ & $\begin{array}{l}\text { Dominance of domestic } \\
\text { private owned enterprises }\end{array}$ \\
\hline Target industries & $\begin{array}{l}\text { Import substituting and } \\
\text { labor intensive industries }\end{array}$ & $\begin{array}{l}\text { Import substituting and } \\
\text { labor intensive industries but } \\
\text { also basic industries }\end{array}$ & $\begin{array}{l}\text { Export oriented and labor } \\
\text { intensive industries }\end{array}$ \\
\hline Envisaged key player & Foreign investment & Public sector investment & Domestic private sector \\
\hline & $\begin{array}{l}\text { Protection of domestic } \\
\text { market through high tariff } \\
\text { and banning of certain } \\
\text { imports. }\end{array}$ & $\begin{array}{l}\text { Protection of domestic } \\
\text { market through high tariff } \\
\text { and quantitative restrictions, } \\
\text { financing, subsidizing, }\end{array}$ & $\begin{array}{l}\text { Direct support for selected } \\
\text { export sectors through } \\
\text { capacity building and other } \\
\text { means. Provision of }\end{array}$ \\
\hline Policy instruments & $\begin{array}{l}\text { Provision of economic } \\
\text { incentives and } \\
\text { preferential credit scheme }\end{array}$ & $\begin{array}{l}\text { ensuring monopoly, power } \\
\text { of the SOECs }\end{array}$ & $\begin{array}{l}\text { economic incentives and } \\
\text { preferential credit scheme }\end{array}$ \\
\hline
\end{tabular}

Source: (Mulu, 2013)

\section{The Contributions of the industrial sector}

In creating job opportunities, urban development, closer support to the agricultural development, and conducive environment for new investors are the central core of economic growth of any nation. Those are influenced by the growth rate of the industrial sector specially manufacturing industries. The major components of this activity involve labor productivity, capital formation, improvements in technology and the market environment (UNIDO, 2009).

Labor productivity: - output per worker. Labor productivity in economic growth refers to how much output per hour, week and so on, results from labor-input. Infarct, output per worker per time as a direct measure of labor productivity. Labor productivity depends upon a number of factors including the population size (quantity) and degree of education and skills (quality) of labor supply, the capital stock other resources; each laborer has to work with and the technology available for production. Educational development and on thejob-training of laborers, growth in human capital is a rather obvious requirement for the productivity increases, but productivity increases are also closely linked to capital formation and technology (UNIDO, 2009). 
Capital formation: the promise to invest capital on the activity, as initial stage is the accumulation of money either through savings domestically or borrowing from financial institution. Capital formation is one of the ingredients of growth in size and quality of capital -stock-the quantity of fixed assets consisting of buildings, machineries, inventories and equipment use in production. Labor productivity is enhanced when capital stock available to labor growth faster than the labor supply. This capital is said to be deepening capital. Increases in capital- stocks are costly. Resources including time must be scarified to produce capital goods that are not directly consumable, so capital growth requires selling or abstention from current consumption. For new investment on machineries, buildings and equipment to grow, society ability have knowledge to make savings. The reword for selling is greater future development in either consumable goods or in more capital goods. In the later sense economic growth is cumulative if feeds on itself by using capital to produce more capital (UNIDO, 2009).

Improvements in technology: technological growth and invention, improvements in methods by which goods and services are produced and sold is another key to economic growth. The industrial revolution of the 17 th $\mathrm{c}$ - 19th $\mathrm{c}$ in western countries ushered in the age of mechanization, increasing the productivity of labor standard of living for the greatest number of people in the recorded history of humanity. Such living standards could be unthinkable without the invention of items such as steam engine, assembly - line production and etc. Technology and invention have been responsible for nothing less than the modern world. The market environment: most western economists believe that the market environment surrounding the growth in natural resources, labor productivity, capital formation and so on, are a large contributing factors to economic growth. A competitive market system may believe encourage invention and rapid innovation. All private and public restraints 0on competition, including excessive or unnecessary regulation or tariffs or quotas on goods exchanged in an international and trade, will trend to reduce the rate of growth in real per capital GNP (UNIDO, 2009).

Exports: While on the face of it, manufactured exports appear to have registered impressive growth in the past few years, a closer look at the structure of exports reveals that leather and leather products, food and textiles in that order constituted the bulk of industrial exports. Manufactured exports are thus limited to agricultural based products. Export earnings generated by the sector have been able to meet only about half the sector's foreign exchange requirements (Dinh, et al., 2012).

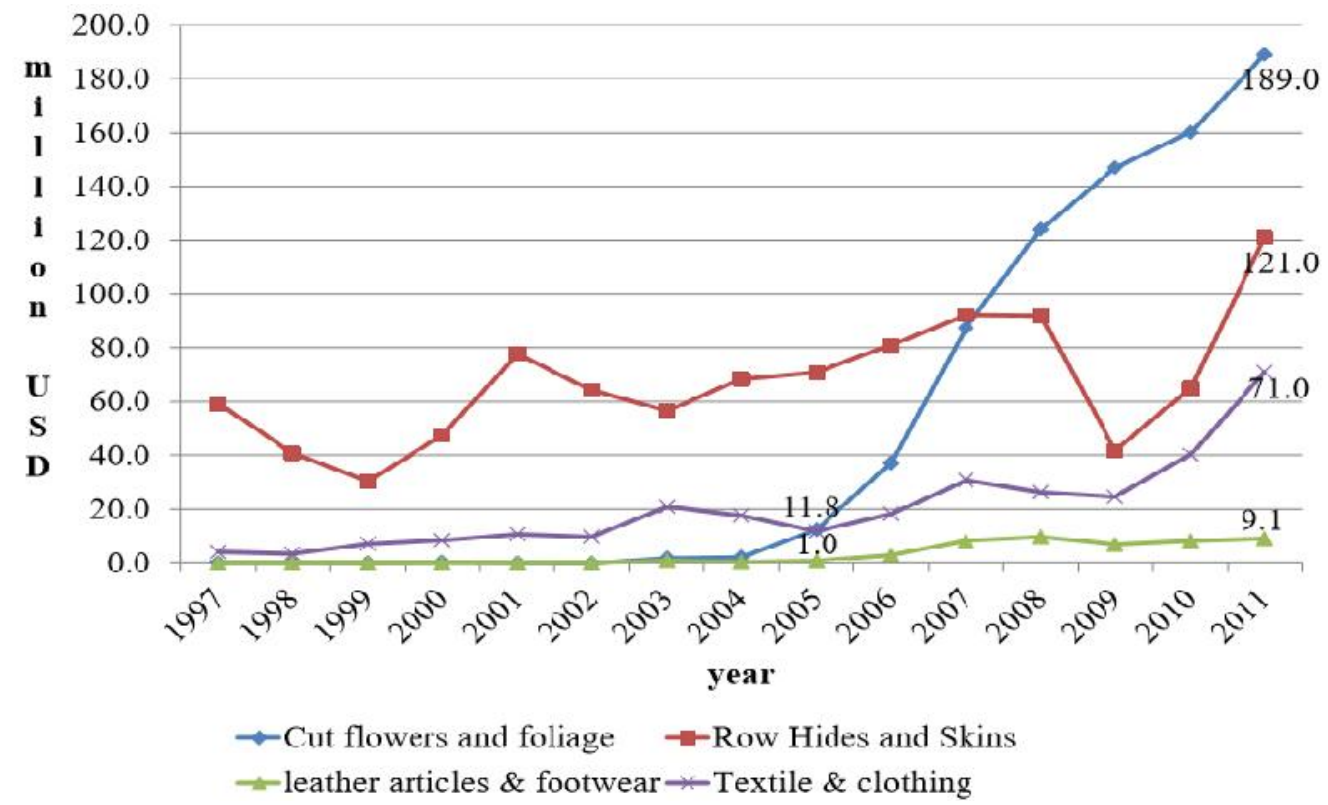

Figure 1. Exports of selected products 1997-2011 

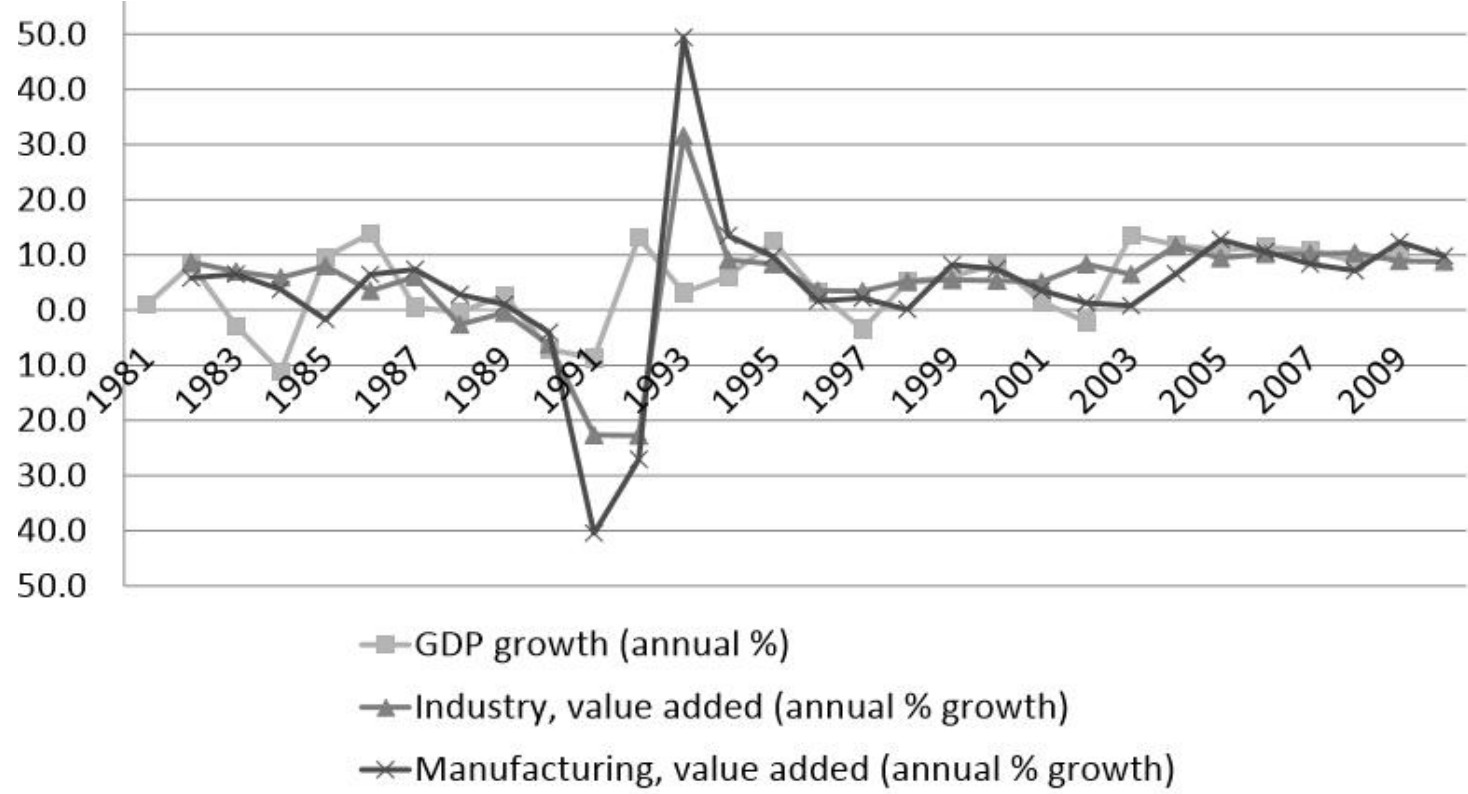

Figure 2. GDP growth, Industry and manufacturing value added (Ethiopia, 1982-2010)

Source: (Mulu, 2013)

Table 2. Sector in the Industry

\begin{tabular}{|c|c|c|}
\hline Sector/ Indicators & Start (2010) & End (2015)] \\
\hline \multicolumn{3}{|l|}{ The industry sector development targets } \\
\hline Sugar production (in thousand tons) & 314.5 & 2250 \\
\hline sugar Export (in million ton) & & 1.246 \\
\hline Revenue from sugar export (in million USD) & & 661.7 \\
\hline Revenue from garments export (in million USD) & 21.8 & 1000 \\
\hline Revenue from export of leather and products industry & 75.73 & 496.5 \\
\hline Total national cement production capacity (in million ton) & 2.7 & 27 \\
\hline Per capita steel consumption (in $\mathrm{kg}$ ) & 12 & 34.72 \\
\hline
\end{tabular}

Source: The Growth and Transformation Plan (GTP I) 2010/11-15/16

Table 3. Share of industrial and manufacturing sector

\begin{tabular}{|c|c|c|c|}
\hline Industry & $\begin{array}{c}\text { Unit of } \\
\text { measurement }\end{array}$ & $\begin{array}{l}\text { Baseline year } \\
(2014 / 15) \text { up to } \\
(2019 / 20)\end{array}$ & Plan \\
\hline \multicolumn{4}{|l|}{ Share of Industry in GDP } \\
\hline percent & $\%$ & 15.6 & 22.8 \\
\hline $\begin{array}{l}\text { Share of Manufacturing industry in } \\
\text { GDP percent }\end{array}$ & $\%$ & 4.6 & 8.0 \\
\hline $\begin{array}{l}\text { Employment opportunities created } \\
\text { by medium and large } \\
\text { manufacturing industry. }\end{array}$ & Number & 380,000 & 750,000 \\
\hline
\end{tabular}

Source: The Second Growth and Transformation Plan (GTP II) (2015/16-2019/20).

\section{Opportunity and constraint of industrial sector Opportunity}

The rapid and sustained double digit economic growth (10.9\% per annum) registered during the last 12 years, investment expansion undertaken in Agricultural Socio-Economics Journal physical infrastructure and human development and the achievement of MDGs have set the springboard for the implementation of GTP II. Furthermore, the Government's firm commitment and transformational leadership with remarkable 
performance in economic growth and social development coupled with the ongoing progress in national image building have helped attract foreign direct investment (FDI). These are considered to be opportunities for implementation of GTPII.

The launching of mega infrastructure projects such as the Great Ethiopian Renaissance Dam (GERD) and other projects of huge national significance such as Gilgel Gibe III and Rail way construction projects (Addis -Djibouti \& the Addis Light Train) have been unique features of the first Growth and Transformation Plan (2010/112014/15). Currently, these projects are at different stages of implementation. The GERD has reached half way through its completion; Gilgel Gibe III and the Addis-Djibouti rail way project is almost near completion and the Addis Ababa light train has already commenced operation. These achievements against ambitious plans of the kind have created a spirit of confidence in the nation. This represents a huge opportunity in mobilizing the public for development endeavors of the kind in the course of implementing GTPII in the coming five years (2015/16-2019/20).

Thus, the achievement of GTPI has been more than what performance figures could tell. One of the success stories during the implementation period of GTPI (2010/11-2014/15) has been in the areas of Natural resource management and watershed developments within the framework of social mobilization undertaken in a structured and coordinated manner. The lessons and experiences drawn from such successful practices will be scaled up and replicated to other sectors in the course of GTP II implementation.

The huge potential for producing inputs for agro-processing manufacturing industries, the capacity being created to supply mid-level trained human power through the on-going TVET programs, potential market opportunities for manufactured products worldwide, market opportunities through the recently renewed duty free access to USA markets through the African Growth and Opportunity Act (AGOA) as well as access to European markets through the EU's Everything But Arms (EBA) initiative are appropriate to be exploited in the course of implementing GTP II. The Growth and Transformation Plan (GTP II) 2010/11-15/16

\section{Constraint}

The inadequacy of infrastructure has been one of the major constraints for the industrial development. Roads, energy, water supply, and other facilities have not been developed to support the industrialization process in the country. Although the country's major natural resource base is its rich agricultural potential, it has not been utilized for the development of the industrial sector. The very low productivity in agriculture resulting from the use of outmoded technology could not cope with the demand for industrial raw materials and foreign exchange requirements, in addition to limiting the market for industrial goods.

Although Ethiopia is known to possess a wide variety of mineral resources, their utilization is yet to be realized mineral exploration and exploitation still being at its infancy. This thwarted the expansion of industries based on mineral resources that would have otherwise made it possible to reap the benefits of comparative advantage. The industrial sector is characterized by very low inter and intra-sect oral linkages. It has been unable to produce intermediate inputs, spare parts and capital goods for its own use as well as for use by other sectors of the economy. The sector itself has continued to be import dependent for machinery and equipment, spare parts and other inputs with no possibilities for self sustained development.

Small and medium scale industries, as well as handicraft and rural industries, were given less priority in the wider spectrum of industrial development. The encouragement and expansion of these industries would have meant an adequate supply of consumer goods, developed domestic entrepreneurship, generated employment opportunities and created inter and intra-sect oral linkages and a balanced regional development. Past industrialization policy was such that it resulted in an unwarranted concentration of industries in and around a few major urban centers. There were no inducements for industrial enterprises to be located in different regions of the country in the interests of promoting balanced regional development.

The industrial sector has been characterized by capital intensive technology. This has led to a number of problems. First, the sector has not been able to generate employment opportunities. Second, having been unable to absorb available labor force, the sector has lost a large potential market for its own products. The absence of 
appropriate institutions for man power development and for the selection, transfer, adaptation and diffusion of technology also remained major constraints for industrial development. The dearth of private and public investment and lack of any consistent public policy aimed at promoting industrial development.

\section{CONCLUSION}

The five years growth and transformation plan is prepared in the Basic Case Scenario and High Case Scenario. The High Case Scenario wills double the 2002 agricultural production and the whole economy by 2015 . These development goals will definitely be achieved if all the citizens of the nation participated at all levels. Therefore, Success in GTP requires high investment. To this effect, there is a need for greater domestic resource mobilization to finance investment demand. By enhancing citizen's awareness about tax, government will increase revenue mobilization and create more fiscal space by rationalizing non investment spending. Encourage the private sectors, cooperatives and households to enhance their culture of saving. Create enabling environment for private sector investment growth.

At the end of the plan period, the industrial sector will be in position to play a leading role in the economy. There will be huge infrastructure investment to promote growth and development as well as generate foreign exchange savings. At the end of the five years growth and transformation plan Ethiopia will definitely meet the MDGs. Good Governance and capacity building will get due attention during the plan period. By 2025, Ethiopia will be a middle income country. The share of the industrial sector from $(2014 / 15)$ up to $(2019 / 20)$ 15.6 to 22.8 , the government needs to increase the industrial sector by reducing the agricultural sector from 41 to 36.5 , and service sector from 43.4 to 41.6. Second Growth and Transformation Plan (GTP II) (2015/16-2019/20).

\section{SUGGESTION}

Encourage foreign investors to invest on industrial sector, especially, on manufacturing activities, because they do not only invest their capital but also new technology. As new technology comes to the country, it is easy to transfer from one firm to another so that possible way of expansion of new technology, without incurring high costs. A high rate of capital accumulation is a necessary condition for bringing about structural transformation and increased level of productivity to raise industrialization, through largely resources channeled into productive investment. The faster the manufacturing sector, the greater the rate of productivity growth; and the industrial sector provides capital goods such as machinery and equipment to other sectors thus contributing to the development of those sectors.

Public infrastructure-networks are essential criteria for expanding manufacturing industry and upgrading its growth rate, thereby enhancing its contribution to GDP, since the scarcity of these services hinder the manufacturing growth in turns industrialization. So, in order to mitigate this kind of problem, infrastructural investment has to be given priority. Thus, to achieve sustainable development in today's context of market and private sector driven development, Ethiopia, requires support from the industrialized countries to build up basic capacities in order to increase capacity utilization through investment expansion activity.

The industrial sector in Ethiopia is least developed in many respects; in terms of volume and quality products, technology status, labor skills and export capabilities. To overcome these problems, the appropriate combinations use of skilled manpower, modern and suitable technologies and investment on both public infrastructures and manufacturing activities should be made.

\section{REFERENCES}

Afro Consult and Trading Plc. 2002. 'The Study on the Impact of COMESA/FTA, Volume III Competitiveness of the Ethiopian Manufacturing Sector'. Addis Ababa: Ministry of Fianace \& Economic Development (MoFED).

Admit Zerihun. 2008. Industralisation Policy and I ndustrial Development Strategy of Ethiopia. Addis Ababa.

Barrett, C. B., Reardon, T., \& Webb, P. 2001. Nonfarm income diversification and household livelihood strategies in rural Africa: Concepts, dynamics, and policy implications. Food Policy, 26(4), 315-331. DOI: $10.1016 / \mathrm{S} 0306-9192(01) 00014-8$ 
CSA. 2003. 'Report on Cottage/Handicraft Manufacturing Industries Survey'. Addis Ababa:

CSA. 2009. Agricultural Sample Survey 2008/09. Report on Area and Production of Crops. Volume I. Statistical Bulletin No. 446. Addis Ababa, Ethiopia

CSA. 2017. Ethiopian over view status of the economy, Addis Ababa, Ethiopia.

Dinh, H., V. Palmade, V. Chandra, and F. Cossar. 2012. Light Manufacturing in Africa: Targeted Policies to Enhance Private Investment and Create Jobs. Volume I. Washington DC:

Federal Democratic Republic of Ethiopia. 2002. 'Ethiopian Industrial Development Strategy'. Addis Ababa: Federal Democratic Republic of Ethiopia (Amharic version).

Federal Ministry of Finance and Economic Development (MoFED). 2006. Building on Progress A Plan for Accelerated and Sustained Development to and Poverty (PASDEP) (2005/06-2009/10). Volume I: Main Text. Addis Ababa, Ethiopia

Gebreeyesus, M., and M. Iizuka. 2012. 'Discovery of the Flower Industry in Ethiopia: Experimentation and Coordination'. Journal of Globalization and Development, 2 (2): 127.

Geiger, M. and C.Grant-Makokera and Rantao. 2012. 'Ethiopia: An Underestimated Regional Power. Available

at: http://www.africaportal.org/articles/2012/10/1 0/ethiopia-underestimatedregional-power (accessed 10 July 2013).

GRIPS Development Forum. 2010. 'Policy Dialog for Industrial Policy Formulation in Ethiopia'. Interim Report Draft. Tokyo: National Graduate Institute for Policy Studies (GRIPS).

Hausmann, R., and D. Rodrik. 2003. 'Economic Development as Self-discovery'. Journal of Development Economics, 72: 603-33. Harvard University

Lin, J. Y., and H. Chang. 2009. 'Should industrial Policy in Developing Countries Conform to Comparative Advantage or Defy It?' Development Policy Review, 27 (5): 483-502.
Mazumdar, D., and A. Maharazi. 2003. The African Manufacturing Firm, an Analysis Based on Firms Survey in Seven Countries in Sub-Saharan Africa. London: Rutledge.

Mekonnen Kassa. 2000. An Overview of the Energy Situation in Ethiopia, in Economic Focus, Bulletin of the Ethiopian Economic Association (EEA), Vol. 3 No.5, October November 2000

Ministry of Finance and Economic Development (MoFED). 2006. 'Ethiopia: Building on Progress A Plan for Accelerated and Sustained Development to End Poverty (PASDEP) (2005/06-2009/10)' Addis Ababa: MoFED.

National Bank of Ethiopia. 2016/17. Quarterly Bulletin, Fourth Quarter, Vol. 23, No. 4, Addis Ababa

Pack, H., and S. Saggi. 2006. 'Is there a Case for Industrial Policy? A Critical Survey'. The World Bank Research Observer, 21(2): 26797.

Rodrik, D. 2004. 'Industrial Policy for the TwentyFirst Century'. CEPR Discussion Paper 4767. Cambridge, MA: Harvard University, Centre for Economic Policy Research.

Shiferaw, J. 1995. 'An Overview of the Economy, 1941-74'. In S. Bekele (ed.), An Economic History of Modern Ethiopia. Dakar: CODESRIA. Singer, H. (1950).

Szirmai, A. 2009. 'Industrialization as an Engine of Growth in Developing Countries, 1950 2005'. UNU-MERIT Working Paper, 200910.

The First Growth and Transformation Plan (GTP II) $(2015 / 16-2019 / 20)$. The last five year report

The Second Growth and Transformation Plan (GTP II) $\quad(2015 / 16-2019 / 20)$. The current transformation plan of the country report

United Nations Industrial Development Organization (UNIDO). 2009. Ethiopia: New Directions of Industrial Policy.

Engineering Capacity Building Program (ECBP). 2008. Ethiopia's leather exports sky rocket'. Available at http://WWW.ecbp.biz/actions/currentactions/ethiopia's-leather-exports. 